\title{
Month-of-the-year Effects in Nepalese Stock Market
}

\author{
Shanta Devi Maharjan'
}

\begin{abstract}
The study investigates the month-of-the-year effects in Nepalese stock market employing composite index along with other nine sub-indices between mid-July 17, 2007 and mid-July 15, 2017. The study finds statistically significant highest average monthly returns in the month of Ashad (mid-June - mid-July) among other eleven months. On contrary, the significantly negative return is found in the month of Bhadra (mid-August - mid-September). It indicates that the Nepalese stock market has specific returns patterns showing inefficient in weak-form of market efficiency.
\end{abstract}

Key words: Calendar effect, Efficient Market Hypothesis, Month-of-the-year effect

\section{INTRODUCTION}

Calendar effects in stock market returns have been one of most important phenomenon to be examined for earning profit in the investment on stock market. Calendar effects consist the day-of-the-week, the end-of-the-month, the month-of-theyear and holiday effects. The one of the most important calendar effects is the monthof-the-year effect. According to the Efficient Market Hypothesis (EMH) theory, there is no calendar effect on stock's returns and no possibility to predict a stock's price based on calendar information. This theory assumes that all investors are rational and market forces determine stock prices. The evidence of growing number of seasonal effects has led to a doubt on "Efficient Markets Hypothesis". The January effect suggests that daily returns are higher in the month of January than in any other months (Cadsby, 1989; Lakonishok \& Smidt, 1988; Cadsby \& Ratner, 1992; Raj \& Thurston, 1994; Mills, Siriopoulos, Markellos \& Harizanis, 2000).

The previous studies examined the existence of seasonal effect regularities in emerging stock markets (Balaban \& Bulu, 1996, Bepari \& Mollik 2009). The emerging stock markets are viewed as fundamentally different from the markets of developed countries. Emerging stock markets are examined comparatively less than those of

1. Mr. Maharjan is Faculty Member at Public Youth Campus, Tribhuvan University. She can be reached at santamaharjan@gmail.com 
developed stock markets. However, conclusions drawn from a few studies of seasonal effects in emerging markets are not sufficient and complete as developed markets. Thus, the studies on seasonal and calendar effect showed that there is need of more study in this regards. Because of limited studied in the seasonal effects in the context of Nepal, there is immense need of conducting study in the Nepalese stock market to measure the existence of such calendar effects. Therefore, the study seeks to investigate the monthof-the-year effects on the stock prices in Nepal. This will provide evidence towards the existence of calendar effects in the Nepalese stock market.

The rest of the paper is organized as follows: Section II presents the review of previous studies, Section III describes the data and methodology, Section IV discusses empirical results. The final section provides concluding remarks.

\section{REVIEW OF LITERATURE}

Fama $(1965 ; 1970)$ introduced the random walk theory which is the basis of market efficiency i.e. Efficient Market Hypothesis (EMH). According to this theory, there is no calendar effect on stock's returns and no possibility to predict a stock's price based on calendar information. However, evidence collected over time suggests that stock returns do not remain constant and the market can be out performed using seasonal or calendar anomaly. Jaffe and Westerfield (1985), Rozeff \& Kinney, (1976) found for the US market that on average returns in January is higher than other months of the year. On the contrary, January effect was rejected for all the three indices that found the higher returns over other months rather than January (Floros, 2008). While empirical evidences in this line are abounding on developed countries, research in emerging capital market has only recently surfaced.

Using the multivariate regression model, Chatterjee and Maniam (1997) found evidence of the existence of the January effect for small firms, but other effects are not detected at any significant levels. However, the result was not consistent with result found by Patel (2008) that the highest positive mean monthly returns reported on the month of November for both BSE and NSE, while in the month of December produced the second highest average returns for both BSE and NSE index.

In Ukrain, Depenchuk, Compton, and Robert (2010) examined the market returns of the stock and bond markets to determine whether they exhibit calendar anomalies including the January effect, weekend effect, and turn-of-the-month (TOM) effect. There was no evidence of a January effect or a weekend effect in the Ukrainian stock and bond markets. However, the results supported a TOM effect in the Ukrainian stock market.

According to Chou, Das and Rao (2011), the large stocks have a significant value premium only in January and loser stocks mainly drive this high January value premium among large stocks at the turn of the year. In contrast with large stocks, the value premium of small stocks occurs only in non-January months (Chou et al. 2011). The study investigated the seasonal effect in the value premium puzzle. The paper tests whether the value premiums observed among large and small stocks are different in January and non-January. 
In an effort to explain the calendar effects in the Johannesburg stock Exchange, Darrat, Li and Chung (2013) observed that no compelling evidence for either a January or December effect in South African Market. On the contrary, the study on January effect, Sudarvel and Velmurugan (2015) confirmed the existence of seasonality in stock returns in Bombay Stock Exchange's banking sector and the existence of January effect.

The study on calendar effects on stock returns in the Nepalese Stock, there was no evidence of the Month-of-the-year effect found in stock returns (K.C. \& Joshi, 2005), using ten years period between February 1, 1995 and December 31, 2004 employing regression equation with seasonal dummies. There is However, higher and positive returns without statistically significant for the month of October.

Bhatta (2009) found that Nepalese stock market was even not efficient in its semistrong and weak form. There was an excess positive return in the month of Kartik. Kartik strategy (buy the stock at the end of the Chaitra and sold them at the end of Kartik) outperforms other strategy not only in terms of return but in risk too (Joshi, 2009). Similarly, Dangol (2010) investigated whether the Nepalese Stock Market generates significant high or low monthly market returns. The study used a set of parametric and non-parametric tests to examine independent mean returns. The findings of this study were two distinct calendar effects in returns for the Nepali stock market. First, average monthly returns for four months from Baishakh (April/May) to shrawan (July/August) are significantly greater than the average monthly returns of remaining eight months of the year. Second, mean returns for Poush (December/January) to Falgun (February/March) are substantially less than those for the remaining nine months of the year. There are two distinct effects: the 'Baishakh to Shrawan effect' and 'Paush to Falgun effect' that are statistically independent of each other.

Although having a number of studies (Gultekin and Gultekin, 1983; Lewis, 1989; Brown and Luo, 2004) in mature stock markets, it is difficult to find more studies into emerging stock markets on calendar effects, like that of Nepal. In most of the cases, the data considered by the studies are of before 2005 (K.C. \& Joshi, 2005, Bhatta, 2009). However, after 2005, the Nepali stock market has dealt with many ups and downs. A study by Joshi (2009) examined monthly seasonality on stock considering the data up to 2008 . However, the very brief study conclusions are drawn on average monthly return and its standard deviation.

The previous studies conducted on monthly effects in the stock market of different countries have not shown similar results. The reason may be different economic environment, investor behavior and technologies. So there is a need to investigate it in the less developed markets like of Nepal for different calendar patterns, mainly monthly anomalies.

\section{THE DATA AND METHODOLOGY}

The study conducted on secondary data using monthly data of overall NEPSE indices and nine sub-indices for last trading day of each of the month between Shrawan 2064 to Ashad 2074 (mid-July 2007 to mid-July 2017). 
Daily logarithmetic returns on NEPSE were calculated from the NEPSE index for the period from mid-July 17, 2007 to mid-July 15, 2017, i.e., Shrawan 2064 -Ashad 2074 using the following equation:

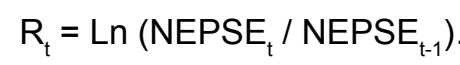

Where, $R_{t}$ is the continuously compounded rate of change in the stock market index. NEPSEt is the stock market index at time $t$ and NEPSEt- 1 is the stock market index at time $\mathrm{t}-1 . \mathrm{Ln}$ is the natural logarithm.

The month-of-the-year effect is tested based on Bikram Sambat months calendar Baishakh to Chaitra using the equation as under.

$$
R=\beta_{1} d_{1 t}+\beta_{2} d_{2 t}+\beta_{3} d_{3 t}+\beta_{4} d_{4 t}+\ldots \ldots \ldots+\beta_{12} d_{12 t}+\varepsilon_{t}
$$

Where, $R_{t}$ is the mean return of the stock index on month $t$. The variable $d_{i t}$ takes a value of one if the return occurs on i month and zero if the return occurs on the month other than i month $\left(d_{1 t}=\right.$ Baishakh, $d_{2 t}=$ Jestha, $d_{3 t}=$ Ashad, $d_{4 t}=$ Shrawn, $d_{5 t}=$ Bhadra, $d_{6 t}$ =Aswin, $d_{7 t}$ kartik, $d_{8 t}=$ Mangsir, $d_{9 t}=$ Paush, $d_{10 t}=$ Magh, $d_{11 t}=$ Falgun, $d_{12 t}=$ Chaitra).

\section{EMPIRICAL RESULT}

\section{1 Descriptive analysis}

The descriptive statistics used in this study consists of number of observation, mean and standard deviation. Table 1 provides the mean monthly returns and standard deviation for twelve months periods including overall NEPSE index along with other nine sub-indices for ten years between July 17, 2007 and July 15, 2017 (Shrawan 1, 2064 to Ashad 31, 2074 B.S.).

Overall average monthly return in the Nepalese stock market (NEPSE) in the month of Ashad is highest mean returns (6.1 percent) among other months. It is followed by the month of Baishakh also generated high returns (2.8 percent). Similarly, first four months from Baishakh to Shrawan generated relatively high returns than other remaining eight months. The reasons behind this result are- the financial institutions dominate Nepalese stock market. It is mandatory for the institutions to publish their quarterly financial reports in national daily newspapers. The third quarters ending in the month of Baishakh, after quarterly reports, investors are able to predict yearly financial situation of the organizations. The next reason is national budget is announced in the month of Ashad, which makes investors aggressive and enthusiastic towards market due to government announcements of upcoming economic programmes and tax rates. Since the highest mean returns from Baishakh to Shrawan, Nepali investors would have earned high returns by investing in these months.

Whereas the months of Mangsir, Paush, Magh and Falgun generated negative mean returns and the result might be as AGM and book closure of the almost companies get completed by the months of Mangsir/Paush. The Nepali investors have nothing to expect from companies and they need to wait for additional six months. This result is consistent with the findings of Dangol (2010) but contradict result with Joshi (2009). 
Table 1: Summary of frequency distribution for monthly stock return from mid-July 2007 to mid July 2017

This table depicts the summary of descriptions of the frequency distributions of the stock returns Sector-wise on the basis of months with 129 observations for the period of Sharwan 2064 - Ashad 2074 (mid-July 2007 to mid-July 2017). The months are considered on Bikram Sambat year as Baishakh is the first month and Chaitra is the last month with No. of observations (N), Mean value and Standerd deviation(Std. Dev.) of monthly stock returns.

\begin{tabular}{|c|c|c|c|c|c|c|c|c|c|c|c|}
\hline $\begin{array}{l}\text { Month / } \\
\text { Sector }\end{array}$ & & com Bank & Manfact & Hotels & Others & Tading & Insurance & Finance & $\begin{array}{c}\text { Dev } \\
\text { Bank }\end{array}$ & Hydro & NEPSE \\
\hline \multirow{3}{*}{ Baishakh } & $\mathrm{N}$ & 10 & 10 & 10 & 10 & 10 & 10 & 10 & 10 & 4 & 10 \\
\hline & Mean & 0.036 & -0.002 & -0.009 & 0.02 & 0.056 & -0.02 & 0.028 & 0.009 & -0.0025 & 0.028 \\
\hline & Std. Dev & 0.0867 & 0.0249 & 0.0145 & 0.0720 & 0.1391 & 0.0414 & 0.0842 & 0.0656 & 0.0665 & 0.0648 \\
\hline \multirow{3}{*}{ Jestha } & $\mathrm{N}$ & 10 & 10 & 10 & 10 & 10 & 10 & 10 & 10 & 4 & 10 \\
\hline & Mean & 0.008 & -0.001 & 0.009 & -0.01 & 0.035 & 0.026 & -0.011 & 0.002 & -0.0675 & 0.008 \\
\hline & Std. Dev & 0.1156 & 0.0260 & 0.0404 & 0.0573 & 0.0670 & 0.0619 & 0.0601 & 0.0745 & 0.2405 & 0.0842 \\
\hline \multirow{3}{*}{ Ashad } & $\mathrm{N}$ & 10 & 10 & 10 & 10 & 10 & 10 & 10 & 10 & 4 & 10 \\
\hline & Mean & 0.08 & 0.024 & -0.001 & -0.004 & -0.002 & 0.019 & -0.001 & 0.018 & 0.195 & 0.061 \\
\hline & Std. Dev & 0.1008 & 0.0645 & 0.0292 & 0.1255 & 0.0225 & 0.0425 & 0.0360 & 0.0454 & 0.1147 & 0.0722 \\
\hline \multirow{3}{*}{ Srawan } & $\mathrm{N}$ & 10 & 10 & 10 & 10 & 10 & 10 & 10 & 9 & 4 & 10 \\
\hline & Mean & 0.017 & -0.02 & -0.003 & 0.098 & -0.004 & -0.011 & 0.012 & 0.0044 & -0.0225 & 0.012 \\
\hline & Std. Dev & 0.0787 & 0.0850 & 0.0424 & 0.3465 & 0.0295 & 0.0433 & 0.0377 & 0.0592 & 0.2176 & 0.0625 \\
\hline \multirow{3}{*}{ Bhadra } & $\mathrm{N}$ & 10 & 10 & 10 & 10 & 10 & 10 & 10 & 9 & 4 & 10 \\
\hline & Mean & -0.074 & 0.04 & -0.005 & 0.006 & -0.004 & -0.014 & -0.014 & -0.0067 & 0.01 & -0.05 \\
\hline & Std. Dev & 0.122 & 0.096 & 0.024 & 0.081 & 0.056 & 0.025 & 0.032 & 0.110 & 0.144 & 0.095 \\
\hline \multirow{3}{*}{ Aswin } & $\mathrm{N}$ & 10 & 10 & 10 & 10 & 10 & 10 & 10 & 9 & 4 & 10 \\
\hline & Mean & 0.015 & 0.004 & -0.01 & -0.041 & -0.015 & 0.001 & 0.016 & 0.038 & -0.0175 & 0.01 \\
\hline & Std. Dev & 0.0448 & 0.0217 & 0.0267 & 0.0939 & 0.0314 & 0.0335 & 0.0704 & 0.1151 & 0.0411 & 0.0356 \\
\hline \multirow{3}{*}{ Kartik } & $\mathrm{N}$ & 10 & 10 & 10 & 10 & 10 & 10 & 10 & 9 & 4 & 10 \\
\hline & Mean & 0.004 & -0.009 & -0.006 & 0.012 & 0.019 & 0.01 & 0.001 & 0.026 & -0.0175 & 0.008 \\
\hline & Std. Dev & 0.096 & 0.025 & 0.014 & 0.091 & 0.030 & 0.033 & 0.078 & 0.122 & 0.043 & 0.075 \\
\hline \multirow{3}{*}{ Mansir } & $\mathrm{N}$ & 10 & 10 & 10 & 10 & 10 & 10 & 10 & 9 & 4 & 10 \\
\hline & Mean & -0.017 & -0.004 & -0.005 & 0.001 & -0.017 & 0.018 & 0.003 & 0.059 & -0.0025 & -0.004 \\
\hline & Std. Dev & 0.0812 & 0.0425 & 0.0276 & 0.0661 & 0.0408 & 0.0916 & 0.0732 & 0.1802 & 0.1179 & 0.0720 \\
\hline \multirow{3}{*}{ Paush } & $\mathrm{N}$ & 10 & 10 & 10 & 10 & 10 & 10 & 10 & 9 & 4 & 10 \\
\hline & Mean & -0.041 & -0.025 & 0.049 & -0.011 & 0.01 & 0.003 & 0.019 & -0.01 & -0.0275 & -0.03 \\
\hline & Std. Dev & 0.0772 & 0.1008 & 0.1277 & 0.0588 & 0.0211 & 0.0869 & 0.1163 & 0.0676 & 0.0206 & 0.0568 \\
\hline \multirow{3}{*}{ Magh } & $\mathrm{N}$ & 10 & 10 & 10 & 10 & 10 & 10 & 10 & 9 & 4 & 10 \\
\hline & Mean & -0.009 & 0.031 & 0.002 & 0.077 & 0.003 & -0.026 & -0.024 & -0.061 & -0.0575 & -0.009 \\
\hline & Std. Dev & 0.0833 & 0.1114 & 0.0336 & 0.2812 & 0.0241 & 0.0479 & 0.0817 & 0.1468 & 0.1001 & 0.0740 \\
\hline \multirow{3}{*}{ Falgun } & $\mathrm{N}$ & 10 & 10 & 10 & 10 & 10 & 10 & 10 & 10 & 4 & 10 \\
\hline & Mean & -0.046 & 0.02 & 0.013 & -0.027 & -0.007 & 0.008 & -0.013 & -0.01 & -0.0675 & -0.032 \\
\hline & Std. Dev & 0.1239 & 0.0583 & 0.0540 & 0.0380 & 0.0302 & 0.0555 & 0.0337 & 0.0616 & 0.0900 & 0.0857 \\
\hline \multirow{3}{*}{ Chaitra } & $\mathrm{N}$ & 10 & 10 & 10 & 10 & 10 & 10 & 10 & 10 & 4 & 10 \\
\hline & Mean & 0.012 & -0.002 & -0.003 & -0.028 & 0.000 & 0.011 & -0.026 & -0.06 & 0.0025 & 0.003 \\
\hline & Std. Dev & 0.0822 & 0.0312 & 0.0258 & 0.0827 & 0.0760 & 0.0702 & 0.0320 & 0.0938 & 0.0629 & 0.0542 \\
\hline \multirow{3}{*}{ Total } & $\mathrm{N}$ & 120 & 120 & 120 & 120 & 120 & 120 & 120 & 113 & 48 & 120 \\
\hline & Mean & -0.001 & 0.005 & 0.003 & 0.008 & 0.006 & 0.002 & -0.001 & 0.000 & -0.006 & 0.000 \\
\hline & Std. Dev & 0.0973 & 0.0655 & 0.0484 & 0.1466 & 0.0585 & 0.0561 & 0.0655 & 0.1019 & 0.1270 & 0.0733 \\
\hline
\end{tabular}

Considering the sectoral returns, Others sector has highest monthly return of 0.8 percent with 0.1466 of risk (standard deviation) in total. Likewise, Hydropower sector seems to offer negative monthly return of 6 percent with 0.1270 . Regarding risk, Others sector shows most risky sector having 0.1466 standard deviation whereas the lowest risk of 0.0484 standard deviation on Hotel sector.

The mean return of Trading and Finance companies are highest in Baishakh, i.e., 5.6 percent and 2.8 percent respectively, likewise, the mean return of Insurance companies is high 2.6 percent in the month of Jestha. The result shows the mean return of Commercial bank and Hydropower is high in the Ashad, i.e., 8 percent and 19.5 percent. Others sectors mean return is high (9.8 percent) in the month of Shrawan. In the same 


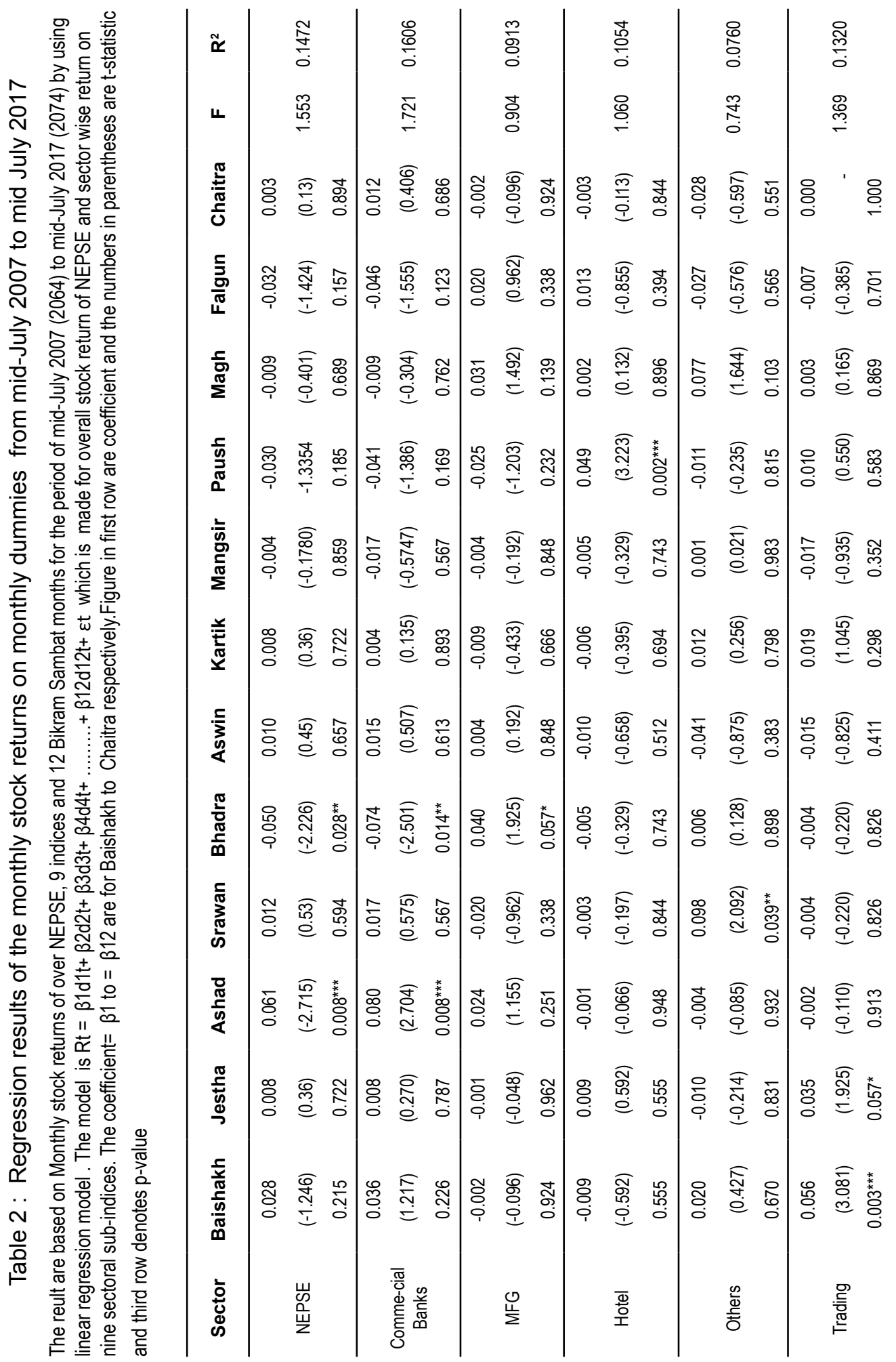




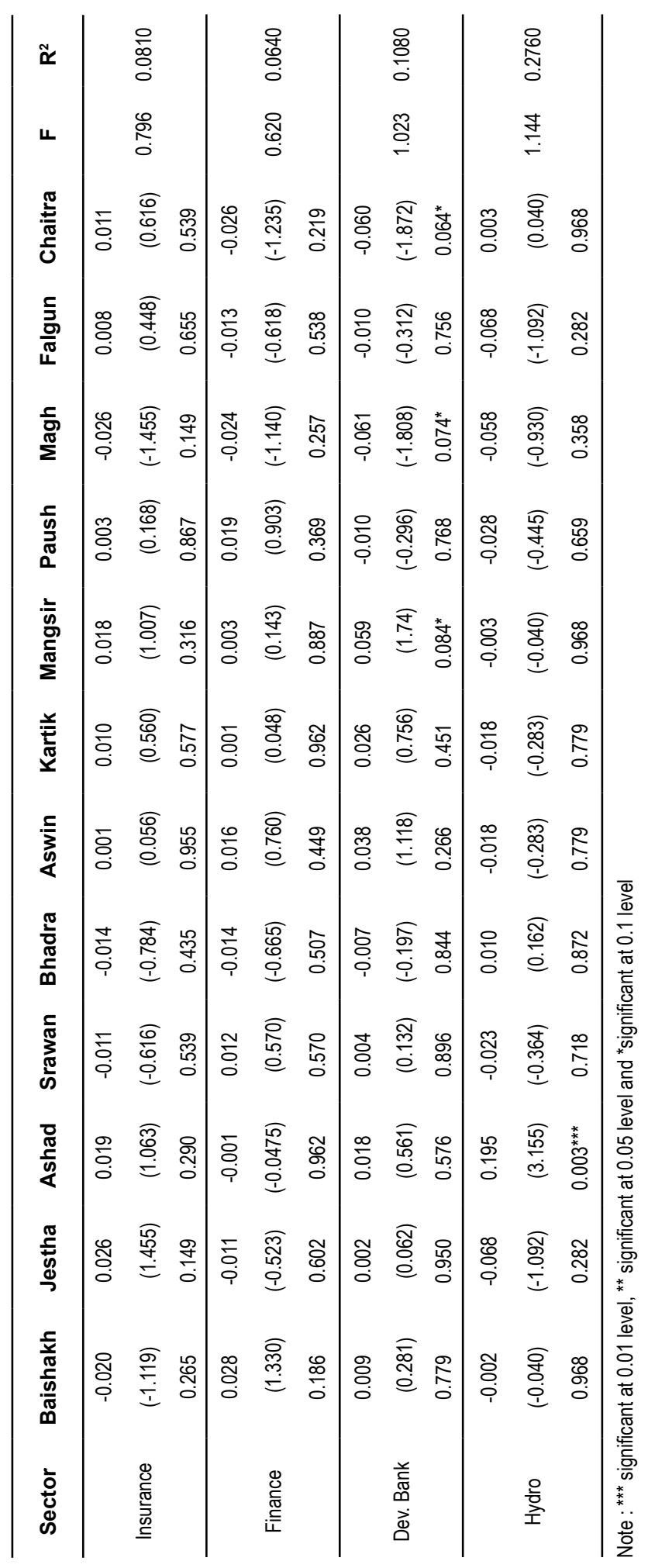


way, manufacturing sector's mean return is high (4 percent) in the month of Bhadra and Development Bank's return is high (5.9 percent) in the month of Mangsir whereas Hotels' return is high (4.9 percent) in the month of Paush. The Mean returns are not significantly different in all the months.

\subsection{Regression Analysis:}

The average monthly return is regressed on Baishakh to Chaitra using the following equation:

$$
\begin{aligned}
R_{i t}= & \beta_{1} d_{1 t}+\beta_{2} d_{2 t}+\beta_{3} d_{3 t}+\beta_{4} d_{4 t}+\beta_{5} d_{5 t}+\beta_{6} d 6_{t}+\beta_{7} d_{7 t}+\beta_{8} d_{8 t}+\beta_{9} d_{9 t}+\beta_{10} d_{10 t}+\beta_{11} d_{11 t}+ \\
& \beta_{12} d_{12 t}+\varepsilon_{i t}
\end{aligned}
$$

Where, Rit is average monthly return for the month $t=\operatorname{Ln}$ (NEPSEt / NEPSEt-1). The $d_{1}$ to $d_{12}$ are dummy variables for month ( $d 1$ takes a value of 1 for all Baishakh observations and otherwise zero and so on. Coefficients $\beta_{1}$ to $\beta_{12}$ are the estimates of the return for each month from Baishakh through Chaitra respectively. Null hypothesis to be tested is - HO: $\beta_{1}=\beta_{2}=\beta_{3}=\beta_{4}=-----\beta_{12}=0$. The null hypothesis considers that the average monthly returns in different months do not differ significantly. If there is existed any statistically significant average return, the null hypothesis is rejected. Table 2 reports the regression result of monthly stock returns of Monthly Dummies.

Table 2 exhibits that the coefficient of monthly returns of aggregate NEPSE for the period of Ashad is the highest positive returns at 1 per cent level of significance among other months' returns. The coefficient of Commercial Bank, Trading and Hotels are positively highest in the month of Ashad, Baishakh and Paush respectively and significance at $1 \%$ level as same Others sector's coefficient is high in Shrawan at 5 percent level of significance. Whereas the coefficient of Development Bank is high positive return in month of Mangsir but result found negative coefficient in Magh and Chaitra at $10 \%$ level of significance.

\section{CONCLUDING REMARKS}

The major conclusion of the study is that the monthly seasonal effect exists on the stock returns in the context of Nepal. The monthly return of overall NEPSE and commercial bank based on Nepalese Bikram Sambat calendar is significantly positive in the month of Ashad. Domination of commercial banks in Nepalese stock market is the major reason of finding the possible reasons of significantly positive return in the month of Ashad. Similarly, the Nepalese Government announces national budget in the month of Ashad, which makes investors aggressive and enthusiastic towards market due to have upcoming economic programmes and tax rates inclusion in budget. Finally the financial year ends in Ashad in Nepal therefore dividends announcement starts of the companies to their shareholders as well as companies start organizing Annual General Meeting (AGM) from beginning of the month of Shrawan as per the Bikram Sambat Calendar.

The overall NEPSE is negative but not significance in the month of Mangsir, Paush, 
Magh, and Falgun. Since the AGM and book closure of the almost companies get completed by the months of Mangsir/ Paush. The Nepali investors have nothing to expect from companies and they need to wait for additional six months. Thus the result shows that the negative return on NEPSE is in the month of Mangsir, Paush, Magh, Falgun. Thus the study has found that the Nepalese stock market exist the monthly seasonal effect. It rejects the weak-form of market efficiency. The market players have opportunity to earn abnormal gain from Nepalese Stock Market.

Thus, the stock price can be predictable and market participants have opportunity to earn abnormal return using the technical analysis. It indicates that the Nepalese Stock market is not efficient in weak-form, and the market is suffered from calendar effect.

\section{REFERENCES}

Bhatta, G. (2009). Stock market efficiency in Nepal, unpublished Ph.D. Thesis. Tribhuvan University. Brown, L. D. \& Luo, L., (2004). The Predictive value of the signs of January returns: Evidence of a New January Effect. Available at SSRN: http://ssrn.com/abstract=525162

Cadsby, B. \& Ratner, M. (1992). Turn-of-month and pre-holiday effects on stock returns: Some international evidence. Journal of Banking and Finance. 16(3), 497-509.

Cadsby, C. B. (1989). Canadian calendar anomalies and the capital asset pricing model in Taylor, S. J., Kingsman B. G and Guimares, R. M. C. (eds). A Reappraisal of the Efficiency of Financial Market. Berlin: Springer-Verlag, 199-266.

Chatterji, A. \& Maniam, B. (1997). Market anomalies revisited. Journal of Applied Business Research. 13(4), 47-56.

Chou, J., Das, P. K. \& Rao, S. P. U., (2011). The value premium and the January effect. Managerial Finance. 37(6), 517-536.

Dangol, J. (2010). Calendar effects in the Nepalese stock market. Nepalese Economic Review. 2(3), 104-109.

Darrat, A. F., Li, B. \& Chung, R. (2013). Seasonal anomalies: A closer look at the Johannesburg Stock Exchange. Contemporary Management Research. 9(2), 155 - 168.

Depenchuk, I. O., Compton, W. S. \& Kunkel, R. A. (2010). Ukrainian financial markets: An examination of calendar anomalies. Managerial Finance. 36(6), 502-510.

Fama, E. F. (1965). The behavior of stock market prices. Journal of Business. 38(1), 34-105.

Fama, E. F. (1970). Efficient capital markets: A review of theory and empirical work. Journal of Finance. 25(2), 383-417.

Floros, C. (2008). The monthly and trading month effects in Greek stock market returns: 19962002. Managerial Finance. 34(7), 453-464.

Gultekin, M. N. \& Gultekin, B. N. (1983). Stock market seasonality: International evidence. Journal of Financial Economics. 12(4), 469-481.

Jaffe, J. \& Westerfield, R. (1985). The week-end effect in common stock returns: The international evidence. The Journal of Finance. 40(2), 433-454.

Joshi, N. K. (2009). Monthly seasonality in Nepalese stock market: Implication for investors. (on line) available: http://epfnepal.com.np/downloads/articles/

K. C, F. B. \& Joshi, N. K. (2005). The Nepalese stock market: Efficient and calendar anomalies. Economic Review. 17(17), 43-88.

Lakonishok, J. \& Smidt, S. (1988). Are seasonal anomalies real? A ninety-year perspective. The Review of Financial Studies. 1(4), 403-425.

Lewis, M. (1989). Stock market anomalies: A re-assessment based on the U.K. evidence. Journal of Banking and Finance. 13(4-5), 675-696.

Mills, T. C., Siriopoulos C., Markellos R. N. \& Harizanis D. (2000). Seasonality in the Athens stock exchange. Applied Financial Economic. 10(2), 137-142(6). 
54 I PYC Nepal Journal of Management, August 2018, Vol. XI, No. 1

Patel, J. B. (2008). Calendar effects in the Indian stock market. International Business \& Economics Research Journal. 7(3), 61- 69.

Raj, M. \& Thurston D, (1994) January or April? Tests of the turn-of-the-year effect in the New Zealand stock market. Applied Economics Letters. 1(5), 81-83(3).

Rozeff, M., William, S. \& Kinney, R. (1976). Capital market seasonality: The case of stock market returns. Journal of Financial Economics. 3(4), 376-402.

Sudarvel, J. \& Velmurugan R. (2015). Janaury effect in Indian banking sector with reference to BSE Bank Index. International Journal of Management Research \& Review. 9(11), 1066 - 1071. 